https://helda.helsinki.fi

\title{
Book review: Kevin Williams, International Journalism
}

\section{Ojala, Markus}

2012-04

Ojala , M 2012 , ' Book review: Kevin Williams, International Journalism ' , Global Media and Communication , vol. 8 , no. 1 , pp. 91-93 . https://doi.org/10.1177/1742766511434736

http://hdl.handle.net/10138/337693

https://doi.org/10.1177/1742766511434736

submittedVersion

Downloaded from Helda, University of Helsinki institutional repository.

This is an electronic reprint of the original article.

This reprint may differ from the original in pagination and typographic detail.

Please cite the original version. 


\title{
Book Review
}

\section{Kevin Williams, International Journalism. London: SAGE, 2011, 216 pp., ISBN: 9781412945288}

\author{
Reviewed by: Markus Ojala, University of Helsinki, Finland \\ Published in Global Media and Communication, 8(1), 91-93. \\ http://journals.sagepub.com/doi/full/10.1177/1742766511434736
}

\begin{abstract}
'The Death of the Foreign Correspondent?' is the somewhat provocative title of the epilogue in Kevin Williams' book International Journalism. Yet the rhetorical question has a familiar ring to it. The future of foreign news is just one of the issues repeatedly raised when concerned academics and elites alike mull over the 'chronic crisis' of quality journalism. Increasing commercial pressures, cuts in the number of foreign bureaus and foreign correspondents as well as the rise of the internet and the 24-hour satellite news networks as alternative sources of international news are often seen as threatening the traditional institutions and the ability of foreign correspondence to continue providing extensive and contextualized coverage of international issues.
\end{abstract}

As ominous as these trends may appear, Williams seems not willing to join the ranks of the pessimists writing obituaries for the trade and its practitioners. In the preface, the author dates the origins of the book back to the 1980s and the Masters programme in Journalism Studies at Cardiff University. The long preparation time shows not only in the wide range of literature from different decades that are cited but more importantly in the book's grasp of the historical changes as well as the continuities in the practice and organization of international journalism. As Williams convincingly demonstrates, foreign correspondence and the business of international journalism have a long tradition of adapting to new and changing environments. Indeed, one of the book's major achievements is to describe how the practice, organization and occupational culture of foreign correspondence have developed over time, following the transformations in technological and social contexts.

The book opens with an introduction to some of the complexities in trying to assess the role of international journalism in contemporary society. Williams focuses particularly on the changes in the epistemic and ideological frameworks marked by the end of the Cold War paradigm, the rise of globalization discourses and the challenges to the Western liberal model of professionalism as the dominant journalistic culture. Without an overarching interpretive frame of the Cold War, foreign correspondents have had to develop a more multifaceted understanding of the world and such globalizing phenomena as pandemics, climate change, migration and human rights. Chapter 1 provides an overview of the relevant debates around globalization and the different ways in which it has been linked to the perceived qualitative shifts in journalism and journalistic cultures. The author argues that instead of homogenization of international news or a universal movement towards cosmopolitan journalism we are witnessing continuing global heterogeneity in the practices and cultures of journalism.

While the historical perspective is employed throughout the book to make sense of various phenomena in international journalism, the history of foreign correspondence is the explicit focus of chapter 2 . This chapter traces the early developments of the occupation and business since the age of European exploration to the end of the colonial era. Two major themes are underlined: the founding of international news agencies in the 19th century and their subsequent control of international news flows, on one hand, and the impact of colonialism on the structures and institutions of international journalism, on the other. As the news agencies operated in close 
relationship with and under considerable control of the colonial powers, colonialism heavily shaped the perceptions of Western audiences of the world outside, establishing many of the patterns or (mis-)representation, negative framing and ethnocentrism into the reporting on the global south that still persist in the Western news media.

The domination of markets by a few international news agencies and the Western bias of reporting, deeply rooted in the era of colonialism, form the backdrop for the rest of the book. Chapter 3 relates the changing fates of the major international news agencies since the Second World War and how their influence has been diminished by the rise of the satellite television networks, big newspapers with their own foreign news services, new ways of producing and disseminating news via the internet, and alternative news agencies. Chapter 4 gives an account of the impact of the changes in the technological and business environments on the actual practices and occupational culture of international news gathering. The diminishing number of foreign correspondents, the increasing use of freelancers, stringers and locals as a source of coverage, the push towards 'generalism' and away from specialist knowledge, as well as growing time pressures and editorial control, are some of the contemporary trends discussed in the chapter.

In chapter 5, the author assesses the power the sources have on shaping foreign news. Particular emphasis is put on governments' practices of propaganda, censorship and political control of international news. Finally, weaving together many of the threads from the preceding discussions, chapter 6 summarizes some of the main characteristics of international news contents. The occupational routines and organizational practices, together with the structural conditions, outside influences and historical narratives, steer international journalism into reproducing several imbalances and biases in its coverage of world affairs. These include over-representation of elites and economically powerful countries, scarce and episodic attention on the global south, tendency to revert to simplistic interpretations of events, and stereotypical representation of 'others'.

Part of the publisher's textbook series Journalism Studies: Key Texts, International Journalism works as a valuable introduction to the field of foreign correspondence and the main themes of its study. Rich in detail but light in theoretical concepts, the text proceeds in close touch with the actual practice of foreign correspondence, frequently referring to famous figures of the trade and using quotes from journalists themselves. This makes it a highly accessible and engaging book for students and teachers alike. However, as a study book it might have benefited from some added references to relevant theoretical discussions and models, especially from the fields of political communication and political economy. Theories of media-state relations, for instance, may have helped to weigh the different pressures and outside influences on international journalism and to assess how much, and in what circumstances, foreign correspondents and their organizations may enjoy autonomy in reporting.

Another theme hardly mentioned in the book is the growing literature on the possibly emerging transnational or global public spheres, which may relate to the described tendencies towards a standardized international news agenda and common frames of reference. Also noteworthy is the absence of any general model of news making, such as Shoemaker and Reese's hierarchy of influences model, which could have been used to illustrate the different and intertwining individual, organizational, institutional and cultural factors that have impact on how foreign news is produced.

In sum, Williams has written a highly accessible yet multifaceted account of the history and current state of international journalism. At the same time, the relative absence of more critical discussions with the academic literature and the lack of a theoretical framework to provide a more encompassing interpretation of the described changes in the field may make the book a somewhat less satisfying read to more advanced students of journalism. 